\title{
THE CONVERTIBLE BOND: A PECULIAR PACKAGE
}

\author{
WILLIAM A. KLEIN†
}

Although convertible bonds ${ }^{1}$ have been widely used for many years, ${ }^{2}$ they have some troublesome characteristics that make them unusually difficult to value ${ }^{3}$ and that raise serious doubts about why they are issued or held. ${ }^{4}$ To put it bluntly,

† Professor of Law, University of California, Los Angeles. A.B. 1952, LL.B. 1957, Harvard University. Member, District of Columbia and Wisconsin Bars. I am especially grateful to C. David Anderson, Esq., Professor Walter J. Blum, and Professor J. Fred Weston for helpful and penetrating comments on an earlier draft. In fairness it should be noted that I rejected some of their suggestions.

${ }^{1}$ I will assume that the reader has a basic familiarity with this type of security. For a good brief description, see W. Eiteman, C. Dice, \& D. EITEMan, The Stock MARKET 350-58 (4th ed. 1966), which provides the following definitional starting point:

A convertible security may be defined as a bond or preferred stock with a contractual clause entitling the holder to exchange it for a number of shares of common stock of the same company within a specified period of time. . .

...

The number of shares of stock obtained for a convertible bond is fixed Id. 350 .

by the terms of the original offering.

The Appendix to this Article will be helpful in suggesting some of the more subtle financial issues. For an excellent summary of the problems of financial analysis, covering both theory and data, see R. Brealey, Security Prices in a Competitive Market 190-203 (1971). In some respects, however, the present paper goes beyond existing financial theory in identifying and emphasizing certain characteristics of convertibles.

2 Convertible securities are of ancient lineage and "have come and gone in financial fashion during the last hundred years." 1 A. Dewing, The Financial. Policy of Corporations 257 (1953).

${ }^{3}$ It seems that even the most sophisticated financial theorists are still struggling with valuation problems far more simple and less realistic than the one I am concerned with here. See Black \& Scholes, The Pricing of Options and Corporate Liabilities, $81 \mathrm{~J}$. PoL. Econ. 637, 640, 648 (1973); Samuelson \& Merton, A Complete Model of Warrant Pricing that Maximizes Utility, 10 Indus. Management Rev., Winter 1969, at 17. The valuation of an option or warrant, which is the focus of these excellent articles, is only part of the problem of valuation of a convertible bond. See note 57 infra.

${ }^{4}$ It might seem inconsistent to suggest that a security could be a bad bargain for both the issuer and the holder. The possibility that this could be the case will be discussed below. See text accompanying notes 21-26 infra. Moreover, there may be reasons why a security should not be held by a particular investor even though it is a "good buy" from the issuer's perspective (for example, when it carries unacceptable risks for that investor). See text accompanying notes 40-43 infra (discussion of the "prudent investor" rule). 
thinking about convertible bonds should trigger the flimflam danger signal in one's mind. This is not to say that convertible bonds should never be issued or purchased. Rather, it means that one should examine convertibles, and more particularly, the reasons for using them, with greater skepticism than I have encountered in most of the financial and legal literature. This idea is not entirely new; ${ }^{5}$ but it is one that seems to be easily forgotten, so that each generation needs to have it recalled.

The plan of the Article is to present a critical analysis of the peculiar financial characteristics of convertible bonds and then to explore some legal issues that emerge from that analysis.

\section{Financial Analysis}

\section{A. Valuing the Bond with a Warrant Attached}

It is useful in examining convertible bonds to focus at the outset on problems of valuation and to start out indirectly with a discussion of a closely related, but less complex and easier to analyze, financing device, the bond with warrant attached. For example, a company might issue a $\$ 1,000$ six percent bond, due in twenty-five years and callable at par plus accrued interest. At the same time it might issue, and attach to this bond, an option or warrant, permitting the holder to purchase forty shares of common stock at $\$ 25$ per share at any time within the next twenty-five years. Suppose that the bond alone would sell for $\$ 800$, a discount of $\$ 200$. And suppose further that the com-

${ }^{5}$ See Katzin, Financial and Legal Problems in the Use of Convertible Securities, 24 Bus. LAw. 359 (1969), referring to a similar view that led to a prohibition on the use of convertible bonds in the Public Utilities Holding Company Act of 1935,15 U.S.C. $\$ 79 \mathrm{~g}$ (c) (1970). C. Pilcher, Raising Capital with Convertible Securities 94 (1955), refers to "an old-line prejudice against complicated security contracts." See also A. DEwING, supra note 2 , at 269.

The discussion in B. Graham, D. Dodd, \& S. Cottle, Security Analysis 603-06 (4th ed. 1968), points out that a person buying a convertible bond probably seeks safety, but if all goes well and the price of the stock rises substantially above the conversion price, the value of the bond will fluctuate with the value of the common; it will become virtually as risky as the common (although the bond element does provide a floor against losses). At this point well beyond the conversion price, then, the safetyminded investor should sell to preserve his gains to that time. Thus, anomalously, the original holder ought to have viewed the convertible bond as a relatively short-term speculation. The authors go on to say that a convertible bond is a compromise between the two conflicting goals of investment and speculation and for the investor "the result is usually confusion, clouded thinking, and self-deception." Id. 606. This suggests the existence of some very schizophrenic investors-or perhaps of speculatively oriented people who are constrained by myopic laws. See text accompanying notes $40-43$ infra. 
mon is currently selling for $\$ 20$ and that the warrant alone would sell for $\$ 200$. By selling both the bond and the warrant the company could raise $\$ 1,000$. The question is: how are these figures arrived at? How much difficulty and uncertainty is involved in the estimation?

Looking separately at the bond and the warrant, it seems reasonable to say that, while the valuation of the bond alone is by no means an easy or nonspeculative task, the difficulties and uncertainties in its valuation fall within familiar and comfortable boundaries. It is a difficult, but manageable, task to determine the likelihood that the issuing company will be able to make the yearly payments of interest and to pay the face amount at the end of the twenty-five year term. Once that likelihood and the market rate of interest ${ }^{6}$ are known, the value of the bond can be determined in accordance with simple actuarial principles. Thus, statements about the value of bonds ordinarily can be made with a fair degree of confidence-with relatively little of the risk associated with lack of adequate information. Likewise, because of the senior claim of this kind of security, there is, ordinarily, relatively little risk associated with economic variables such as industry trends and management performance.

Warrants, when initially issued, ${ }^{7}$ are on the opposite end of the spectrum of uncertainty and risk, with common stock somewhere in between bonds and warrants. The common stock of a company will, of course, be a more risky investment than its bonds. The value of the common is subject to greater uncertainty and greater variability for the obvious reason that the returns to the common are more uncertain and variable. Because the future price of the warrant will be a magnified function of the future price of the common stock, and since the warrant itself introduces problems of valuation, ${ }^{8}$ the valuation of the

6 The rate of interest is set in light of both anticipated future and known present market conditions. In the economist's perfect market, expectations concerning future market conditions would be fully reflected in present price or interest rates.

${ }^{7}$ After issuance, the price of the common may rise, and to the extent that this happens, the degree of leverage or magnification afforded by the warrant will decline, because at some sufficiently high price the ultimate exercise of the warrant becomes a certainty and the price of the warrant will approximate the price of the common stock into which it can be converted. See J. Weston \& E. Brigham, Managerial Finance 474-76 (4th ed. 1972). At the time of issuance, however, the value of a warrant is certainly a magnified function of the value of the common stock into which it is converted. The same may be said of the value of the conversion privilege in a convertible bond.

${ }^{8}$ See authorities cited in note 3 supra. See also Reiling, Warrants in Bond-Warrant Unils: A Survey and Assessment, 70 Mich. L. REv. 1411 (1972). 
new warrants will involve even greater uncertainty and variability; the warrant will be a riskier investment than the common. ${ }^{9}$ For example, using the previous hypothetical figures, for $\$ 200$ a person can buy either ten shares of the common or a warrant granting the right to purchase forty shares. If the market price of the common remains at $\$ 20$ during the entire twenty-five year period, the purchaser of the warrant will lose his entire $\$ 200$ investment but the holder of the common will neither gain nor lose. If the warrant is exercised when the price of the stock is $\$ 30$, the warrant holder will realize a gain of $\$ 5$ per share, or a total gain of $\$ 200$ on the forty shares subject to the warrant, and will thus break even. For each dollar the price of the common rises above $\$ 30$ per share, however, the holder of the warrant costing $\$ 200$ stands to gain $\$ 40$, while the person who invested the same $\$ 200$ in the common will gain only $\$ 10 .^{10}$

Of course, a further source of difficulty and uncertainty in the valuation of the warrant is the cost of money. At a stock price of $\$ 30$ per share, the warrant holder may be said to break even only if the cost of money is ignored. Only as the price of the stock rises above $\$ 30$ per share will the investor be able to recover not only his full $\$ 200$ but enough more to compensate for the foregone return on that amount during the period between purchase and exercise of the warrant. How much extra must be realized on conversion or sale of the warrant in order to compensate adequately for the foregone return on the $\$ 200$ will depend on the length of time between purchase and exercise of the warrant. The period of time until exercise will thus be an important variable in any ex ante determination of the value of the warrant.

The length of time until exercise of the warrant will depend in turn on a factor that may be difficult to predict with confidence, the company's dividend policy. ${ }^{11}$ If the company pays no dividends, the warrant holder should not exercise the warrant until the last moment before expiration; he has nothing to gain

"The purchase of a warrant is similar to the purchase of the common on borrowed money combined with a stop-loss order. Thus, warrants and other options may be seen as devices for avoiding margin requirements, which no doubt helps explain the concern of the Securities Exchange Commission over expanded opportunities for trading in options. See SEC Securities Exchange Act Release No. 10490 (Nov. 14, 1973).

${ }^{10}$ At the same time, however, the market price of the warrant will rise, see note 7 supra, so that continued holding of the warrant will no longer provide leverage.

${ }^{11}$ The financial literature by and large ignores this important factor. 
by earlier exercise and by exercising would lose the return in alternative uses of the additional funds required to exercise the warrant, while at the same time exposing himself to some danger that the price will later fall so much that he could then buy the stock at a yet lower price than the $\$ 25$ per share called for in the warrant contract. ${ }^{12}$ Exercise well before expiration might be appropriate, however, if the dividends that would be realized on exercise exceeded the potential returns on the $\$ 25$ per share exercise price in alternative investments. For example, if the company were paying $\$ 1$ per share when the risk-free market rate of interest was eight percent, obviously it would make no sense to exercise the right to buy at $\$ 25$ per share even if the market price of the stock were, say, $\$ 50$ per share. It would make no sense, that is, to trade a certain $\$ 80$ per year on the $\$ 1,000$ needed to exercise the warrant for an uncertain (or even a certain) $\$ 40$, the total dividend on the forty shares, because the holder of the warrant would continue either way to enjoy the value of any further increase in the market value of the common prior to the expiration date. If, on the other hand, the company began to pay $\$ 3$ per share, making the total dividend $\$ 120$, there would be a strong incentive to exercise the purchase privilege. The actual decision to do so, however, would depend on the value of holding the warrant in order to protect against the risk that the value of the stock might fall below the $\$ 25$ exercise price, which would depend in turn on the present price and price volatility of the common, as well as upon predictions about future dividends and upon risk considerations. ${ }^{13}$

12 The value of this protection afforded by delay is questionable because the investor who exercises the warrant can achieve similar protection by entering a stoploss sell order. See Weil, Segall, \& Green, Premiums on Convertible Bonds, 23 J. Finance 445 (1968). The execution of a stop-loss order will, of course, deprive the investor of the possibility of later gain, so that the purchase-with-stop-loss-order is not the same kind of free ride (free, that is, once we view the cost of the warrant as irretrievable, which we must do to examine whether a feature of the warrant has value) as that achieved by holding the warrant, but this is not a significant difference. See id.

13 The valuation uncertainty associated with uncertainty concerning dividend policy, as it affects length of time until exercise, may not be great. It is reasonable to assume that the retention of earnings will increase the value of the stock. If the company retains earnings rather than paying dividends, the incentive to exercise will be diminished, the length of time to exercise will increase, and the opportunity cost of the warrant (the foregone return on the $\$ 200$ purchase price) will increase. At the same time, however, the value of the common stock and the derived value of the warrant will increase because retention of earnings will increase the value of the stock. The precise effect of the dividend policy on the investor's valuation of the warrant depends, then, upon the relation between the opportunity cost of purchasing the warrant. af- 
Regardless of its impact on the opportunity cost of purchasing a warrant, "normal" dividend policy (how much of current earnings is paid out as dividends) ${ }^{14}$ will have a substantial effect on the value of the warrant. Because that policy is a management prerogative, ordinarily not constrained by the warrant contract, the result may be a significant source of uncertainty in valuation. This uncertainty does not affect the common. To illustrate, ignore taxes and assume that the stock is selling for $\$ 20$ per share and earns $\$ 2$ per share. Assume further that the company has unlimited additional opportunities to make investments that will yield a ten percent return. If the company pays out the $\$ 2$, the stock should continue to be worth $\$ 20$; the shareholder will have the $\$ 2$ plus the stock worth $\$ 20$ and his total wealth with respect to this investment will be $\$ 22$. The shareholder's total wealth will also be $\$ 22$ if the company retains the $\$ 2$, because the value of the stock can be expected to rise to $\$ 22$. The illustration simply states the kernel of common sense in the "irrelevance-of-dividends" thesis, which holds that shareholders ought to be indifferent to dividend policy, given certain assumptions about investment decisions (or, in my model, opportunities) and ignoring taxes and transaction costs. ${ }^{15}$

Now note how greatly the position of the warrant holder differs from that of the shareholder. Holding all other things equal, if the company continues to pay out $\$ 2$ each year, the value of the stock will never rise above $\$ 20$ and the warrant will ultimately be worthless. If, on the other hand, it retains the $\$ 2$ earnings each year for twenty-five years, the value of each share should rise to about $\$ 217^{16}$ at the end of that period and the warrant holder would realize a gain of $\$ 7,480(\$ 8,680$, the value of forty shares, less the $\$ 200$ cost of the warrant and the $\$ 1,000$ payment on exercise)-a nice return on a $\$ 200$ investment. In reality one would have to take account of tax factors, though they would appear not to affect the relative positions of the common and the warrants, transaction costs, and limits on in-

fected as it is by the time that the warrant must be held before exercise, and the effect that retention (or nonretention) of earnings has upon the value of the stock and the derived value of the warrant.

${ }^{14}$ Cf. Berle, Convertible Bonds and Stock Purchase Warrants, 36 YALE L.J. 649, 656-57 (1927), pointing to the possibility of dividends that strip the company of its surplus.

${ }^{15}$ For a clear and concise explanation of this thesis, see V. Brudney \& M. ChIRELSTEIN, CoRporate Finance 427-30 (1972).

${ }^{16}$ The $\$ 20$ initial value plus the compounded value at 10 percent of the $\$ 2$ annuity for 25 years. 
vestment opportunities. These factors would make the figures less dramatic, no doubt. Nonetheless, it should be clear that normal dividend policy will have a significant effect on the value of the warrant.

\section{B. Additional Complexities of Convertible Bonds}

\section{Valuing the Convertible Bond}

It should be clear by this point that the bond with warrant attached is itself a peculiar package-a combination of two elements, the bond and the warrant, that are at opposite ends of the spectrum of risk and certainty. Bearing that in mind, we can now turn to convertible bonds, which are basically the same package, but with one more element that seems as unrelated to the other two as they are to each other. This added element consists of a rather bizarre kind of gamble on changes in the market rate of interest. ${ }^{17}$ In the case of the convertible, the exercise of the option to convert is tied to a surrender of the fixed payments established in the pure bond element of the security. In the event of conversion, any changes, subsequent to issuance, in the market value of the right to fixed payments become irrelevant. Ordinarily this gamble does not exist for the holder of a bond with warrant attached: ${ }^{18}$ with that security, the holder must pay cash for the stock subject to the option; he can retain the bond, so if he decides simultaneously to dispose of the bond, he will suffer or benefit from any changes in its value

${ }^{17}$ It is this added element that made it useful to begin the analysis with the bond with warrant attached. This element of value has been completely ignored even in the more sophisticated analyses of the value of convertibles. See, e.g., Brigham, An Analysis of Convertible Debentures: Theory and Some Empirical Evidence, 21 J. Finance 35, 36 (1966). Perhaps the appropriate inference from this observation is that this element is of trivial significance, but that is not self-evident to me.

${ }_{18}$ See Hills, Convertible Securities-Legal Aspects and Drafismanship, 19 CalrF. L. Rev. 1 (1930). "[T $T$ he only essential difference" between a warrant and a conversion privilege is that ordinarily "[a] warrant is exercised by the payment of cash, while a privilege of conversion is exercised by the surrender of a corporate obligation or a share of stock." Id. 4. This difference will, of course, mean that an exercise of a conversion privilege will not result in an inflow of cash to the company, while the exercise of a warrant will. Thus, it is conceivable that when a company has issued bonds with warrants attached, it may find itself with cash that it doesn't want. But its position is not really much different from what it would have been had it issued convertible bonds, because presumably funds generated by the exercise of warrants can be used to redeem, or purchase on the market, bonds from which warrants have been (or can be) detached. 
that have occurred since the time of purchase independently from the exercise of the warrant. For example, imagine again a convertible bond with a maturity value of $\$ 1,000$ and a coupon rate of six percent, convertible into forty shares of common. Suppose that the bond alone, without the conversion privilege, would have sold for $\$ 800$ initially. Suppose that the market rate of interest rises substantially after issuance and that as a result the value of the bond alone falls to $\$ 600$. As it has turned out, the company has borrowed at a favorable rate. It is better off than its competitors that must raise money at the current rates. Correspondingly, the holder appears to have lost his gamble on the trend of interest rates. If it happens, however, that the value of the common as a current holding (a function of its market price and dividends) has increased to the point that the bondholder would have converted in the absence of a change in the market rate of interest, then the effect of the change in the market rate of interest will become irrelevant to him. ${ }^{19}$ Looking at the same phenomenon from another perspective, when the holder contemplates purchase he will properly take account of the coupon rate and terminal value in determining the present value of the bond. He knows that if he were buying a straight

${ }^{19}$ It may also be noted that upon conversion the original issue discount (the difference between the $\$ 1,000$ terminal value and the $\$ 800$ initial value of the bond element) also becomes irrelevant; in a sense, that discount is recovered on conversion. (This is a plausible rationale for disallowing the issuer any tax deduction for original issue discount on the debt element.) See note 93 infra. The amount of the recovery will, of course, be a function of the length of time remaining to maturity, but we can view the gain in this respect as offset by the loss of the investment in the option element. In my analysis in the text $I$ take a different view, assuming that the full $\$ 1,000$ initial investment will be recovered one way or another and that consequently the cost of the option is simply the foregone interest on $\$ 200$. The analysis seems to be the same on either view. To illustrate, return to the case of the bond with warrant attached. Here, if the warrant is exercised, the discount on the bond is not recovered. Imagine that not to be the case, but that on exercise of the warrant, the company were required to call the bond at par. It would be as if the cost of the warrant were the foregone interest on the bond (the difference between coupon rate and market rate on $\$ 1,000$ ), because the full $\$ 1,000$ is recovered, plus the reduction in return that the issuing company would have insisted upon in recognition of the possibility of early conversion. Alternatively, it would be as if the cost of the warrant were $\$ 200$, plus foregone interest on that amount, less the portion of the initial discount on the bond that is recovered. Either way, the analysis of the relative value of the elements in a convertible bond seems more complex than the analysis of the relative values of a bond and attached warrant, but this is like a computational complexity, relating only to the relative value of the two elements, rather than the kind of gamble that is examined in the text. For further application of this point, see the Appendix. That is why the analysis in the text is concerned only with discounts and premiums arising from changes in the market rate of interest subsequent to issuance. 
bond its value would change as the market rate of interest changed, but the value of the convertible bond will change as the market rate of interest changes if, and only if, the value of the common has not risen to the point where conversion is appropriate. Specification of the complex relations suggested by this observation is beyond the scope of this paper, but the following observations seem in order. First, the practically random relation between the interest rate and the price of this particular common stock injects a variable that increases the already complex, difficult, and uncertain task of valuing a convertible bond (and derivatively, the other outstanding securities of the same company). Second, this particular variable can be eliminated by the use of the bond with warrant attached. Finally, and consequently, it is difficult to imagine any rational investor who would willingly choose to include this variable, this bizarre gamble, in the investment package represented by the other features of the convertible bond, unless he thereby obtained the investment at a markedly lower price than that at which he could obtain separately the other desirable elements of the package. ${ }^{20}$

\section{Do Convertible Bonds Make Any Sense?}

This last observation suggests a related but far more fundamental question that can be raised about the issuance of either a convertible bond or a bond with warrant attached, though with greater force for the former. The bond and the option (warrant or conversion privilege) are, as stated earlier, at opposite ends of the spectrum of both risk and difficulty of valuation. Presumably they are the types of securities that would appeal to different investors, or at least to a single investor for different purposes. In an unregulated market one would expect that the use of a package or tie-in like that reflected in a convertible

${ }^{20}$ The convertible bond contains at least one other element of risk and uncertainty not found in the bond with warrant attached. A warrant will have a fixed expiration date. A conversion privilege will, of course, expire when the bond matures, but it will also expire within some short period after the issuer calls the bond for redemption. Notice of redemption usually, but not always, will be issued when the price of the common has risen to a point where conversion is assured, so the possibility of such notice can be seen as imposing a limit on the potential gain from the conversion privilege. Because it appears that issuance of notices of redemption for convertibles is not solely a function of the price of the common, see Walter \& Que, The Valuation of Convertible Bonds, $28 \mathrm{~J}$. FINANCE 713, 721 (1973); note 56 infra, the redemption possibility adds yet another element of uncertainty and risk to the convertible bond that is not associated with the bond with warrant attached. 
bond would reduce the potential proceeds to the company, unless there are substantial savings in flotation costs achieved by selling the package as opposed to selling the separate elements (and in an efficient securities market it is hard to see why there should be such savings). Selling a package consisting of a bond and an option is like selling a package consisting of a combination of apples and oranges-it deprives the seller of the opportunity to obtain the best possible price by fully exploiting the separate demands for each product. ${ }^{21}$ For example, ${ }^{22}$ suppose $S$ has available for sale 100 apples and 100 oranges, and suppose that buyer $B A$, an apple lover, is willing to pay $\$ 10$ for 100 apples and $\$ 2$ for 100 oranges, while $B O$, an orange lover, is willing to pay $\$ 10$ for 100 oranges, and $\$ 2$ for 100 apples. If $S$ sells his apples to $B A$ and his oranges to $B O$ he will realize $\$ 20$. If, on the other hand, he were willing only to sell the apples and oranges together to a single buyer he could expect to receive no more than $\$ 12$, from either $B A$ or $B O$.

A priori one would expect the same analysis to apply to a financial package consisting of disparate elements. It will be recalled that in the case of convertible bonds, the package consists of the bond, the option, and the bizarre gamble on the market rate of interest-analogous to a package of apples, oranges, and a lottery ticket-while in the case of the bond with warrant attached the package consists of the first two of the three elements. Again, for simplicity's sake, consider the bond with warrant attached. Returning to the previously used hypothetical figures, suppose that investor $I B$ would be willing to pay $\$ 850$ for the bond and $\$ 150$ for the warrant while investor $I W$ would be willing to pay $\$ 750$ for the bond and $\$ 250$ for the warrant. ${ }^{23}$ If the company were to sell the bond and warrant as a package it would receive only $\$ 1,000$, from either $I B$ or $I W$. If, on the other hand, it were to sell the bond and warrant separately it could realize a total of $\$ 1,100$ : $\$ 850$ from $I B$ for the bond and

${ }^{21}$ See R. BREALEY, supra note 1, at 189: "Jack Spratt's Law is basic in finance."

22 I beg the indulgence of the reader if $I$ seem to belabor this point. The review of fundamentals seems justified by the apparent fact that they are widely ignored-as witnessed by the very existence of convertible securities, by the absence of discussion of the tie-in problem in the financial and legal literature, and by the contrary position taken by a leading authority like Dewing. See note 25 , infra. It may be that the analysis, though sound, is counterintuitive.

${ }_{23}$ The difference in demand would most likely be attributable to different taste, or distaste, for risk, with $I W$ having a greater tolerance or preference for risk than $I B$. 
$\$ 250$ from $I W$ for the warrant. It might be true, of course, that there would be a buyer who would be perfectly satisfied with the package, ${ }^{24}$ someone who was looking for precisely that combination. Modern portfolio theory does suggest that it may be sensible for a particular individual desiring a given level of overall risk to achieve that level of risk with a combination of low risk and high risk securities. But a buyer looking for the precise package embodied in a particular convertible bond would be rare, and would be a potential customer for each element of the package even if those elements were sold separately. Assuming the separate availability of bonds and options, one would expect that the demand for the package would be significantly lower than the combined demand for the separate elements, ${ }^{25}$ which

24 One can imagine, for example, an investor who wants to gamble on a longrun increase in the price of the common, and who at the same time wants to set aside a fund to be used for the ultimate acquisition of the common, though the two decisions are certainly not necessarily connected (because, for example, a person can cash in on a winning gamble without acquiring the common stock simply by selling the warrant at a profit to someone who will buy the common stock). The bond with warrant attached might be a convenient, low-transaction-cost means of doing this. Again, however, it is certainly not necessarily true that a person attracted by the common stocks of a company would view the same company as the appropriate one for his lower-risk investments. Moreover, it seems that a better strategy for an investor with the posited objectives might be simply to buy the common, while at the same time entering a stoploss sell order, note 12 supra, though that strategy might involve unacceptable transaction costs.

It has also been suggested that in mergers, the owners of the securities of the acquired company may be peculiarly attracted by such a package. Pinches, Financing with Convertible Stocks, 1960-67, $25 \mathrm{~J}$. Finance 53, 59 (1970), has this to say of the use of convertible preferred stock (which is, on this point, equivalent to a convertible bond) in mergers:

A... reason for employing convertible preferred stock to finance mergers is as a means of reconciling divergent cash dividend policies between acquiring firms and the firms to be acquired, while enabling the acquiring firm to keep its existing cash dividend policy on common stock .... Inspection of the present 481 mergers verified that many of the acquiring firms paid little or no cash dividends. In such cases convertible preferred stock serves as an expedient means of adjusting divergent cash dividend policies between merging firms.

251 A. Dewing, supra note 2 , at 270 , argues, however, that the market price of a convertible bond may be greater than the combined market prices of its separate elements because the convertible has appeal for people in all ranges of the risk-preference spectrum. This is like saying that a package of apples and oranges will sell for more than the price that apples and oranges separately would bring because the package appeals to both apple lovers and orange lovers. That makes no sense as long as apples and oranges may be bought separately. In the case of convertible bonds, hovever, it appears that the separate elements are not available separately; long term options are not readily available, except to high-level employees. One should wonder why companies are willing to sell such options as part of a package but not separately. I suggest that such speculation will support a disdain for the use of convertibles. 
means that the issuer will not maximize its returns, even though few, if any, buyers will obtain a bargain. ${ }^{26}$

By this point, if not earlier, one should have begun to question why companies ever issue convertible bonds, at least for the purpose of raising new capital. ${ }^{27} \mathrm{~A}$ number of reasons have been suggested, ${ }^{28}$ but only two have even enough superficial purely economic rationality to deserve consideration. ${ }^{29}$ One reason is associated with the view that a convertible bond is basically debt financing, with the conversion privilege as a "sweetener." 30 The reason for adding the sweetener by issuing a convertible, rather than a straight bond, is to reduce the interest cost or, to put the same idea in slightly different terms, to permit the sale of a bond at an interest cost such that the company's appearance as a good credit risk will not be impaired. ${ }^{31}$ What this boils

${ }^{26}$ See R. BREALEY, supra note 1, at 201-02 (1973) (making the point that the issuer presumably would be better off issuing a bond with detachable warrant than it would be issuing a convertible bond); Lavely, Comparative Usage of Bond-Warrant and Convertible Bond Issues, $26 \mathrm{~J}$. Finance 796 (1971). The convertible bond might be more attractive, however, to purchasers who contemplate that they will convert and become holders of the common if the price rises-that is, for those who expect at the outset ultimately to convert and who want to have a fund hedged against changes in the market rate of interest in that event only. As to the rationality of such a strategy, see note 24 supra.

${ }^{27}$ For a discussion of what may be special considerations in mergers, see note 24 supra.

${ }^{28}$ See, e.g., C. Pilcher, Raising Capital With Convertible Securimies 84-85 (1955).

${ }^{29}$ I ignore for now the possibility that the demand for convertibles may be artificially increased by certain legal curiosities. For a consideration of constraints on investment opportunities of fiduciaries, see text accompanying notes $40-43$ infra. For possible tax effects, see note 39 infra and text accompanying note 61 infra.

${ }^{30}$ See, e.g., American Bar Foundation, Corporate Debt financing Project, Commentaries on Model Debenture Indenture Provisions 524 (1971) [hereinafter cited as Commentaries on Model Debenture Indenture Provisions]; J. W'eston \& E. Brigham, supra note 7, at 479; Hayes \& Reiling, Sophisticated Financing Tool: The Warrant, 47 HaRv. Bus. Rev., Jan.-Feb. 1969, at 137, 139.

${ }^{31}$ See Hayes, New Interest in Incentive Financing, 44 Harv. Bus. Rev.. July-Aug. 1966 , at 99,100 , referring to a "mystical consensus" in the financial community as to what is a respectable interest rate. A rate above this level:

is likely to cause heads to shake and eyebrow's to raise among investment decision makers at the inferred quality of the credit involved. In the words of one institutional investment officer, whose attitude is typical of other lenders with whom I have talked, "I wouldn't dare present a $71 / 2 \%$ loan to my investment committee, even if I rere convinced that it represented an acceptable risk."

Much the same attitude is evidenced by business managers of companies seeking to borrow capital from such institutional investors. Oftentimes, they do not want to show a financing with an abnormally high interest charge on their books for fear it will indicate weakness or instability.

In order to avoid the unfavorable appearance, issuers added "an incentize feature 
down to is flimflam. ${ }^{32}$ The cost of raising the money is not reduced at all, of course; it is just disguised, unless there is only a negligible chance that the price of the common will, in fact, rise to the point where conversion will be attractive to the bondholders. By selling the conversion privilege the company in effect receives a payment for a gamble on the common stock, . and uses that payment to reduce the apparent cost of capital. I offer no insight into who is deceived-management, existing shareholders, or purchasers of the bonds, or all of them.

The other most significant reason for issuing convertibles is associated with the view that they are essentially a form of deferred equity financing. ${ }^{33}$ The idea behind this view is that management may want to raise equity capital, but it considers that the current market price of the common is too low. ${ }^{34}$ Convertible bonds are issued, therefore, with the idea that they will be converted into common when the value of the common rises to a point where the company can force conversion by calling

which served as a substitute for additional interest income." Id. These "incentive features" (What a dandy euphemism! Why not "hidden substitutes for interest"?) consisted of conversion privileges, warrants or options, and bonus stocks. One cannot resist noting that the anonymous investment officer quoted above must have thought either that the members of his or her investment committee were stupid, or that they acted for principals who were stupid, or both.
32 [Another] reason for financing mergers with convertible preferred stock could be the desire, on the part of the acquiring firm, for immediate earnings leverage. Under our present accounting convention, an immediate increase in reported earnings available for common stock is normally possible if a merger occurs with convertible preferred stock. As long as the after-tax earnings of the acquired firm are greater than the dividend requirements on the newly issued convertible preferred, [the] merged firm will show increased earnings. These increased earnings may be temporary or permanent depend- ing on the conversion terms, actual rates of conversion, and the reporting of potential dilution resulting from future conversion. Due to the increased emphasis on earnings performance, this reason, by itself, may largely ex- plain why convertible preferred stock became increasingly important in fi- nancing corporate mergers during the study period.

Pinches, supra note 24, at 59. Such a tactic (but using debt rather than preferred stock) does increase earnings, but only at the expense of the increased risk associated with debt financing. The market value of earnings should, of course, be adjusted downward to account for the risk. See J. Weston \& E. BRigham, supra note 7, at 189-200. Moreover, one should note that the tactic requires debt financing, but not necessarily the use of convertible debt.

${ }^{33}$ See, e.g., Commentaries on Model Debenture Indenture Provisions, supra note 30, at 523 ; J. Van Horne, Financial Management and Policy 369 (3d ed. 1974); J. Weston \& E. BRIGHAM, supra note 7, at 479.

${ }^{34}$ But see $R$. BREALEY, supra note 1 , at 202 which refers to evidence consistent with "a tendency for managements to issue convertibles when they suspect their stocks are overvalued." Perhaps this merely proves again that anyone interested in the behavior of business people must look to what they do, not what they say they do. 
the bond. But if the common looks like such a good buy, why let the purchasers of the convertible bonds in on the expected rise in value? Is it not true that by selling the option, the company's officers are gambling that the stock will not perform as well as the buyers expect? If the market price of the common rises and the bonds are converted, then, to be sure, the company will receive more for the stock than it would have received if it had sold the stock at the time of issuance of the bond, but it will receive less than it would have received for the stock if the bond, with its conversion privilege, had never been issued. For example, assume that the company issues the bond when the price of the common is $\$ 20$ per share; that the bond is convertible at $\$ 25$ per share (that is, convertible into forty shares); and that the market value of the conversion element of the bond is $\$ 200$ or $\$ 5$ per option share. ${ }^{35}$ Ignoring foregone interest, the breakeven point for the investor is $\$ 25$ per share. ${ }^{36}$ The buyer must be gambling that the price will rise above $\$ 25$. Correspondingly, the company must be gambling that the price will not rise above that level-otherwise it would have issued a straight bond and sold common, retiring the bonds, when the price did rise to some point above $\$ 25$. This seems like a rather peculiar kind of gamble for the corporate managers to be taking, betting against the rise above $\$ 25$. It might be argued that the managers might not have the option of issuing straight debt because the interest rate might be "too high." But as we have already seen, that cost is not reduced by issuing the convertible, it is merely disguised. It might also be argued that transaction $\operatorname{costs}^{37}$ are reduced by issuing the convertible bonds, but the harder one thinks about this claim the less sense it seems to make given the possibility, for instance, of raising equity capital at relatively low cost by issuing rights to shareholders. ${ }^{38}$

${ }^{35}$ This is a difficult assumption to make, since the cost of the conversion element is a function of the length of time between issuance of the bond and exercise of the conversion privilege. See text accompanying notes 10-12 supra.

${ }^{36}$ Ignoring foregone interest on the $\$ 200$, the "loss" of the investment in the conversion privilege is offset, upon conversion at this point, by the "gain" from the recovery of the initial imputed discount on the bond element.

${ }^{37}$ I refer here to the transaction costs of the issuer. It is conceivable that a buyer who contemplated exercise of the conversion privilege might reduce his transaction cost by buying a convertible bond as opposed to a bond with warrant attached or a warrant and a separate bond. See note 24 supra. The existence of such persons would, of course, tend to improve the demand for the convertible bond.

${ }^{38}$ See J. VAN HoRne, supra note 33, at 330 . Van Horne says that the issuance of rights to buy shares at a price below market will dilute the earnings per share and 


\section{LEgAL Issues}

The foregoing financial analysis of convertible bonds is by no means exhaustive but should serve to raise some questions in the minds of financial analysts. It should also raise some serious questions in the minds of lawyers, and I now turn to those legal issues. $^{39}$

\section{A. Prudent Investments}

It appears that the demand for convertible bonds may be improved, over what it would be in an unregulated market, by virtue of the fact that purchase of such securities permits certain institutional investors to engage in speculation that cannot be engaged in directly. ${ }^{40}$ Institutions and fiduciaries that would

counts that as a disadvantage of the use of a rights offering as a method of raising capital. Since the shareholder will have been compensated for the dilution, see id. 327, it is difficult to see in what respect the dilution is any more a disadvantage than is, say, the dilution associated with a stock dividend.

39 I will avoid the complex and inconsistent rules relating to the income taxation of issuers and holders of convertible bonds. See generally, Fleischer \& Cary, The Taxation of Convertible Bonds and Stock, 74 Harv. L. Rev. 473 (1961); Reiling, supra note 8, at 1445-71; Note, The Tax Consequences of Redemption of Convertible Bonds, 49 B.U.L. REv. 96 (1969). Those rules seem to be largely the product of a rather unique tax legislative and administrative history, see Hunt Foods \& Indus., 57 T.C. 633 (1972), aff'd per curiam, 496 F.2d 532 (9th Cir. 1974), and of peculiarities of the tax laws, such as provisions creating the opportunity for taking an ordinary deduction and then selling at capital gain rates, see Commissioner v. Korell, 339 U.S. 619 (1950), and therefore are outside the scope of this Article. Very briefly, there are inconsistent tax treatments of discount and premium. In determining the amount of premium that it must take into account as income, the issuer excludes that portion of the sale price of the convertible bond that is allocable to the conversion feature. Treas. Reg. $\$ 1.61-12$ (c)(2) (1957). Correspondingly, the holder, in determining the amount of premium that may be deducted through amortization over the life of the bond, must exclude the same portion of the sale price. INT. REv. CODE of 1954, § 171(b)(T) (last sentence). In other words, for this purpose there is a separation of the two elements. On the other hand, to compute the amount of original issue discount on the bond element that he must report as income (ratably over the life of the bond), the holder ignores the value of the conversion feature; he determines the existence of discount as if there were no such feature. AMF Inc. v. United States, 476 F.2d 1351 (Ct. Cl. 1973), cert. denied, 94 S. Ct. 2639 (1974); Chock Full O' Nuts Corp. v. United States, 453 F.2d 300 (2d Cir. 1971); Hunt Foods \& Indus., 57 T.C. 633 (1972), aff'd per curiam, 496 F.2d 532 (9th Cir. 1974); INr. Rev. Code of 1954, § 1232(b); Treas. Reg. \$ 1.163-4(a) (1971).

Similarly, I will ignore the securities law problems generated by the peculiar nature of convertible bonds. Like the tax problems, the securities law problems seem to be largely the product of a unique history and set of objectives that place them beyond the scope of this Article. See 1 Loss, Securities Regulation 673-87 (1961); Gadsby, Private Placements of Convertible Securities, 15 Bus. Law. 470 (1960).

${ }^{40} \mathrm{~A}$ related phenomenon also deserves brief mention. It has been said that one of the reasons for the popularity of convertible bonds is that margin requirements are lower for them than for common stock. See, e.g., Fleischer \&. Cary, supra note 39, at 475. Until last year banks could lend up to $35 \%$ of the value of common stock and $50 \%$ of the value of convertible bonds. Board of Governors, Federal Reserve Sys., Reg. U, 
not be permitted to buy straight calls or other options on common stock, or to buy unattached warrants, regardless of how heavily weighted their total portfolio was in favor of the most conservative investments, nonetheless are permitted to buy convertible bonds. ${ }^{41}$ This is true even though a convertible bond can sensibly be viewed as a straight bond plus a call, warrant, or option. The prudent investor rule that produces this anomaly appears to be founded on the simplistic notion that a convertible bond is "essentially" a bond-a view that not only ignores the conversion privilege but also ignores the prevailing, though equally simplistic, view that a convertible bond is "essentially" a form of deferred equity financing. ${ }^{42}$ It is certainly a procrustean policy that permits the holding of a set of securities of homogeneous risk while foreclosing the holding of a set of securities of different degrees of risk, but with the same overall risk as the former set. ${ }^{43}$ One can argue, therefore, that an institution

12 C.F.R. $\$ 221.4$ (1973). But see 39 Fed. Reg. 1006 (1974) (raising the loan value of common stock to 50\%). (Brokers and dealers were subject to a similar rule, Reg. T, 12 C.F.R. 220.8, also amended by 39 Fed. Reg. 1006 (1974), but New York Stock Exchange Rule 431, 2 C.C.H. N.Y.S.E. GuIDE $\{2431$, sets a $75 \%$ margin requirement for each type of security.) With this modest spread, the borrowing advantage of convertibles was significant mostly in situations in which the price of the bond was virtually equivalent to the price of the common stock into which it could be converted. In such situations it made little sense to distinguish the bond from the underlying stock for margin purposes. See note 7 supra. This phenomenon was related to the one discussed in text in that in both instances the convertible bond was treated like a bond and not like a common stock.

${ }^{41}$ See, e.g., Commentaries on Model Debenture Indenture Provisions, supra note 30 , at 523. The "prudent investor" rule that governs trustees, guardians and other fiduciaries in situations in which no specific statute or other governing instrument applies, seems to allow for some latitude in choosing safe and risky investments, but does not seem to permit the holding of any single investment that is above an acceptable level of risk regardless of the overall level of risk of the portfolio. Indeed, in the discussions of the rule, one finds no mention of the possibility of achieving an acceptable level of portfolio risk through a combination of investments some of which might be extremely risky. See, e.g., A. Loring, A Trustee's Handbook 209-10 (Farr rev. 1962); 3 A. Scotr, Trusts $\$ 227$ (1967); Note, The Regulation of Risky Investments, 83 Harv. L. Rev. 603 (1970). See also Cal. Civil Code $\S 2261$ (1954), adopting the prudent investor rule in terms referring only to the possibility of investments in bonds, preferred stock, and common stock. It seems to be tacitly assumed that a convertible bond is viewed as a whole and can therefore fall within the rubric, "prudent investment." In light of relatively recent developments in investment theory, see, e.g., J. Francis \& S. Archer, Portfolio Analysis 111-17 (1971), it is by no means inconceivable that a court could be convinced that the proper measure of prudence was the overall riskiness of the portfolio, not the riskiness of its riskiest components. But reliance on that prospect would be a risky venture itself, without adequate reward in most instances.

${ }^{42}$ See note 33 supra.

${ }^{43}$ Within customary ranges of relative value of the bond element and the conver- 
should be allowed to hold a modest amount of warrants, calls, or other options as long as its other holdings are such as to produce an overall level of risk that is acceptable. To foreclose the pursuit of such an investment openly and directly, while allowing it indirectly, is the height of absurdity. One wonders when the lawmakers will awaken to financial reality.

\section{B. Disclosure}

Prevailing accounting standards now require that the possibility of conversion of bonds be brought forcefully to the attention of investors. ${ }^{44}$ This is consistent with the view of convertible bonds as deferred equity financing, ${ }^{45}$ but in some circumstances it might make at least as much, and perhaps more, sense to view the conversion privilege as a gimmick used to disguise the true cost that a company must pay for its capital. ${ }^{46}$ Even if the investor can be assumed to understand that the interest rate does not represent the full cost of capital where convertible bonds are concerned, he has no way of knowing how much greater than the apparent interest rate the true cost may be. It is puzzling that protectors of the investors' claim to information

sion element, a convertible bond at time of issue will ordinarily be regarded as a safer investment than the common stock of the same company. See Brigham, supra note 17 , at 43 . As the market value of the common rises, the value of the convertible bond will become equivalent to ownership of the common stock. It then becomes a riskier investment than it was when first issued-that is, when the pure bond element was a significant part of value. See id. 37. Yet I presume that even if the prudent investor rule permitted a trustee to invest entirely in a portfolio of common stocks without fear of criticism, if he invested in a portfolio consisting of, say, $90 \%$ bonds and $10 \%$ warrants of the same company, he would be liable for losses on the warrants.

${ }^{44}$ Reports of earnings per share must reveal the potential effects of dilution through exercise of conversion privileges and other options. Accounting PRINCIPLES Bd., Opinion No. 15: Earnings Per Share, in 2 APB Accounting Principles 6609 (1973). In the case of convertible bonds, the effect could be to show a potential increase in earnings per share, if interest charges exceeded current earnings on the number of shares into which the bond could be converted. This possibility arises from the fact that when conversion is assumed for purposes of determining the number of shares outstanding, the interest (after taxes) on the bond must be restored to income. Id. 6613 n.4 \& 951 . This possibility supports the suggestion in the text accompanying notes 46-50 infra as to reporting the true rate of interest.

45 Indeed, once the price of the common stock into which the bond is convertible has reached a point where conversion can readily be forced by calling the bonds, perhaps it is misleading for the balance sheet to continue to show the bonds as outstanding debt. An unsophisticated reader of a balance sheet that treats such bonds as debt might be misled as to such matters as the cost of raising new capital or the practical freedom of the company to pay dividends. One wonders whether prospective lenders treat such bonds as debt. See note 45 infra.

${ }^{46}$ See text accompanying notes 30-32 supra. 
have not insisted that the true cost of borrowing be revealed, for example, by at least a footnote in the annual report saying that the interest on the indebtedness would have been $x+y$ percent instead of $x$ percent if, in connection with the borrowing, the company had not granted, without other compensation, a call with a market value of $\$ z$.

The fact is, however, that the Accounting Principles Board of the American Institute of Certified Public Accountants has directed its members to proceed in quite the opposite direction. ${ }^{47}$ In a recently issued opinion it observes that in the case of a convertible bond the debt and the conversion feature are inseparable, that the two elements are not ordinarily held separately, that conversion and redemption are mutually exclusive, and that "the holder cannot exercise the option to convert unless he foregoes the right to redemption and vice versa." 48 This aspect of inseparability and mutual exclusivity of options is given as the principal reason for the conclusion that "no portion of the proceeds from the issuance of . . . convertible debt securities . . . should be accounted for as attributable to the conversion feature."49 To this line of reasoning perhaps the best, and only, response is the classic quip, "I understand everything but the 'therefore." "50 The opinion does not specifically address itself to the kind of informational note that I have suggested, and it is difficult to see how anyone focusing on the investor's interest in information could object to such a note. It is true, however, that such a note might be an embarrassment to man-

${ }^{47}$ Accounting Principles Bd., Opinion No. 14: Accounting for Convertible Debt and Debt Issued with Stock Purchase Warrants, in 2 APB Accounting Principles 6603 (1973).

${ }^{48}$ Id. If 7.

49 Id. If 12. The opposite conclusion is reached, however, with respect to bonds issued with detachable warrants. Id. If 17. The fineness of the distinction between the two types of securities, plus the vacillating language of the opinion, supports the view that it could only have been written by a committee of strong-minded people forced to reach agreement despite their fundamental differences.

so The opinion also points out that it would be extremely difficult to value the conversion feature and that this is a secondary reason for not accounting for it separately. No such valuation is necessary; valuation of the debt element is all that is needed (though presumably the value of the conversion feature could be inferred from this figure plus the sale price of the bond). In justifying their conclusion, the accountants did not place much reliance on this valuation problem. This is understandable in light of the fact that Moody's Bond Record purports to supply the appropriate valuation figure for all publicly traded convertible bonds-presumably on the assumption that the financial community will find the information useful. Thus, the argument of the Board comes down to the non sequitur that information concerning the values of the separate elements should not be revealed simply because those elements are legally inseparable and are not in fact separately traded. 
agement, and the implication of the opinion seems plain enough that a respectable accountant has no business trying to convey such information.

\section{Drafting the Indenture and Normal Dividend Policy}

It appears that normal dividend policy can have a significant effect on the value of the conversion privilege and thus on the value of the convertible bond. This being so, and inasmuch as the interests of the common shareholders and the holders of the convertible bonds are in potential conflict on the issue, one might expect that it would be commonplace for convertible bond indentures to contain provisions constraining dividend policy. This does not appear to be the case. ${ }^{51}$ For example, the American Bar Association-sponsored model indenture goes only so far as to preclude the kinds of dividends that might impair the solvency of the company or might reduce the initial equity cushion. ${ }^{52}$ In the financial literature I have found no mention of the basic issue stemming from normal dividend policy. Perhaps the reason for the omission from the financial literature is that in the short run, dividend policy is likely to be predictable and not of very great importance. Moreover, the financial analysts tend to think of convertible bonds as deferred equity financing, with conversion contemplated in the near term. But what about the lawyers? Lawyers typically pride themselves on anticipating and providing for all significant contingencies, as attested by the length of the typical bond indenture. Why, then,

${ }^{51}$ Kaplan, Piercing the Corporate Boilerplate: Anti-Dilution Clauses in Convertible Securities, 33 U. CHI. L. REv. 1, 12 (1965), refers to the problem of a change in policy by which dividends are increased, and to other dividend problems, and says that "[o]ccasionally anti-dilution clauses provide for adjustment upon such events," but the "typical provision" that supposedly addresses itself to such problems allows dividends to the full extent of any earnings arising subsequent to the date of the indenture. See id. 12 n.23. Thus, in my terminology, the typical provision imposes no constraints on "normal" dividend policy.

52 See Commentaries on Model Debenture Indenture Provisions, supra note 30 , at 547 , presenting, in connection with the problem of protecting the conversion privilege, a model provision that allows dividends "out of earnings or any surplus legally available for dividends under the laws of the state of incorporation of the Company." In other words, the company is bound by the indenture to do no more than it is already bound to do under the state incorporation law. Curiously, the model optional provisions (ones normally to be negotiated) restricting dividend payments for protection of straight bonds contemplate the possibility of far more severe restrictions. Id. 410-21. And the discussion of antidilution contemplates the possibility that small stock dividends, e.g., one to three percent, should not require a change in the conversion ratio. Id. 546 n.21. See also Hills, supra note 18, at 24. 
have they not been more alert to the significance of normal dividend policy and to the need for a negotiated resolution of the inherent conflict? One answer that might be offered is that the magnitude of the issue is not great enough to justify the effort, at least in the case of bonds that are callable at prices that will not allow the value of the conversion privilege to become very large. But the value of the conversion privilege can easily be twenty percent of the value of the entire package, and one wonders how difficult it would be to insert an appropriate provision limiting dividends to a percentage of earnings consistent with past dividend policy. Such a provision might prove to be unnecessary in the sense that the company might not be inclined to alter its past practices, but certainly the same could be said of much of the "boilerplate" in bond indentures. My own conjecture is that the problem has been ignored because convertible bond indentures are drafted by bond lawyers, who concentrate on the problem of protecting against insolvency and tend to view the conversion feature as a relatively trivial, or at least a rather distasteful, appendage interesting to irresponsible gamblers, but not to good, solid investors. Thus, they provide for only the most significant and obvious aspects of protecting the conversion privilege. That is pure speculation, but the failure to insist on the type of provision I have referred to seems to be a fact and it is one that ought to be disturbing to a careful lawyer.

\section{Dividend Policy and the Duty of Directors}

If my analysis of the significance of normal dividend policy is correct, and if that policy is not constrained by any provision in the bond indenture, then a question might arise as to the duties of the directors in declaring, or failing to declare, dividends. Suppose that the directors decide to pay no dividends. A present shareholder could object on the ground that this decision will tend to produce a windfall for the convertible bondholders at the expense of the shareholders. On the existing state of the law it is scarcely conceivable that a court would interfere with a conscious decision of the board resulting from a balancing of this negative effect on the value of shares against competing considerations. As a general rule, "whether or not dividends shall be paid, and the amount of the dividend at any time, is primarily to be determined by the directors, and there must be bad faith or a clear abuse of discretion on their part to justify 
a court of equity in interfering." ${ }^{\prime 3}$ But what if it could be established that the board had failed even to consider the potential detriment to existing shareholders? Might not such a failure constitute a failure to exercise due care and thus give rise to a cause of action seeking damages or an injunction? It is unlikely that the shareholders would be able to prove their case, but even if such a suit had little chance to succeed, it would, and should, be an embarrassment to the directors.

Next, imagine that the board, in a dramatic reversal of prior policy, decides to pay out all current earnings as dividends. Is this a violation of their duty to the bondholders? Ordinarily one would not assume that the duty to the bondholders extended beyond paying interest and repaying principal on maturity. ${ }^{54}$ This notion seems consistent with the view that the holders of convertible bonds are like other bondholders-"essentially" creditors. But the financial analysts tell us that convertible bonds are often viewed by the issuers as deferred equity financing. ${ }^{55}$ The holders of those bonds, under this view, might then be viewed as entitled to be treated as quasi-shareholders to whom the directors owe a duty of loyalty. It might be contended that if the bondholders wanted protection against a liberal dividend policy they should have insisted on it during the negotiation of the indenture (which again raises an issue as to the duty of the indenture trustee, and its lawyer, to insist on such a provision), but that begs the question, because if the bondholders are viewed as shareholders who are temporarily entitled to certain special benefits, such as guaranteed income, then perhaps the duty is on the directors, at the time of issuance, to insist on a clause specifying their lack of obligation to avoid injurious dividend policy.

${ }^{33} 11$ W. Fletcher, Cyclopedia of the Law of Private Corporations $\$ 5325$, at 630 (perm. ed. rev. 1971). See, e.g., Kroese v. General Steel Castings Corp., 179 F.2d 760, 763 (3d Cir.), cert. denied, 339 U.S. 983 (1950); cases collected at 11 W. FLETCHER, supra, 635 n.5. For a brief discussion of limitations on directors' discretion, see United States v. Byrum, 408 U.S. 125, 140-42 (1972).

${ }^{54}$ The traditional view is that the convertible bondholder is strictly a creditor, until conversion, and cannot complain of otherwise legal actions of the corporation, not prohibited in the indenture, that diminish the value of the option. See Gay v: Burgess Mills, 30 R.I. 231, 74 A. 714 (1909) and cases cited therein; Hills, supra note 18, at 4: "The holder of a convertible obligation is not a stockholder in equity or at law nor is he a subscriber to shares of stock of the issuing company .... It has therefore been held that such holder has no right to question the declaration or payment of cash or stock dividends ...." See also Berle, supra note 13, at 651 .

${ }^{55}$ See note 33 supra. 


\section{E. Forcing Conversion}

Where the company can force conversion by calling the bond, there might be potential director liability for failure to do so. Imagine this situation: the bond pays $\$ 60$ per year interest and the call price is $\$ 1,100$. The current market price of the common stock is $\$ 50$ per share. The bond is convertible into forty shares of common; no dividends are being paid on the common and it is contemplated that none will be paid in the next several years. By forcing conversion the company would save the $\$ 60$ per year, or $\$ 31.20$ per year after tax effects, and would eliminate the bondholders' priority over shareholders in the event of bankruptcy. Would not a failure to call at this point, if not earlier, be extremely irresponsible to the shareholders? In my view the answer to that question is clearly "yes," but as I examine bond guides I find companies that have failed to call their convertible bonds in what seem to be similar situations. ${ }^{56}$ Even in less extreme situations there may be an obligation to call, but it is doubtful that directors are generally aware of this obligation and their potential liability for failure to discharge that obligation.

Precisely when an obligation to force conversion would arise, short of the extreme situations, presents a difficult problem. In my search of the basic financial literature I have been unable to find any adequate discussion of the point at which a convertible bond should be called. ${ }^{57}$ It has been said that the call

${ }^{56}$ For example, on October 4, 1973, the Xerox Corporation had outstanding $\$ 155,584,000$ of convertible bonds, callable at 105.4 and convertible at a price of $\$ 92$ per share. Moody's Bond Recond, Sept. 1973, at 56. As of October 4, the dividend rate was \$.88 per share. Wall Street J., Oct. 5, 1973 at 25, col. 3 (Eastern ed.). Hence, the dividend on the shares into which the bond could be converted was $\$ 9.56$, while the interest rate on the bond was six percent, or $\$ 60$ per annum (costing the corporation $\$ 31.20$ after the tax deduction). Id. 24, col. 4. Because the lowest price at which Xerox common sold in 1973 , as of October 4 , was $\$ 134.00$, id. 25 , col. 3 , while the lowest price at which it sold in 1972 was $\$ 120.50$ per share, 2 Moody's Indus. Manual 3309 (1973), a call would clearly have forced conversion and saved the company money. It is possible that other factors militated against forcing conversion, however. See text accompanying notes 57-59 infra.

According to Brigham,

[Corporate] policies range from calling as soon as they are "sure" conversion will take place-this generally means a premium of about 20 percent over the call price-to never calling at all. If the policy is to never issue a call, however, the firm generally relies on the dividend-interest differential to cause involuntary conversion.

Brigham, supra note 17, at 39. See also id. 52; Walter \& Que, supra note 20, at 721.

${ }_{57}$ Brigham, supra note 17 , comes closest to providing a complete list of the relevant parameters and some guide to their interrelationships. 
should not be issued until the market price of the shares into which the bond can be converted is around twenty percent above the redemption price of the bond. ${ }^{58}$ The reason given for waiting until that much discrepancy has appeared is that the company should be certain that the bond will be converted so that it will avoid refinancing costs: there is typically a significant time between the notice of call and the expiration of the right to convert, during which time the market price of the stock might fall to a point where conversion would not occur unless the initial price of the common is substantially higher than the con-. version price. This analysis suggests that a rational decision to call or not is a function of market price of the common, volatility of that price, length of time from notice to expiration of conversion privilege, the cost of refinancing, and, of course, the number of shares into which the bond may be converted. As the example suggests, however, the decision should also be a function of the level of interest payments, the company's tax position, and the company's current and projected dividend policy. The market rate of interest and the level of retained earnings might also be relevant. It might also be relevant, especially if the company were contemplating raising new capital, that forcing conversion would improve the company's equity-debt ratio, though a sophisticated lender might not be concerned about debt that can easily be eliminated by forcing conversion.

Do the directors expose themselves to liability for failure to exercise due care if they do not attempt to take account of all, or at least the most obviously significant, of these factors in a reasonably systematic fashion? In this era of Texas Gulf Sulphur ${ }^{59}$ and its progeny, can one comfortably rely on the notion that legal definition of the minimal level of such responsibility is unprecedented?

\section{F. The Tax Deduction for "Interest"60}

Interest is deductible for purposes of federal income taxation of corporations, but dividends are not. It seems quite plain that under existing rules distinguishing between interest and

${ }^{58}$ See, e.g., J. VAN HoRne, supra note 33, at 370; Bacon \& Winn, The Impact of Forced Conversion on Stock Prices, 24 J. Finance 871 (1969).

34 SEC v. Texas Gulf Sulphur Co., 401 F.2d 833 (2d Cir. 1968).

${ }^{60}$ For a general discussion of this issue, see Warren, The Corporate Interest Deduction: A Policy Evaluation, 83 Y ALE L.J. 1585 (1974). 
dividends, the payments on most convertible bonds are to be treated as interest and are therefore deductible, ${ }^{61}$ but perhaps the present tax doctrine reflects too formalistic an approach. I refer again to the notion that convertible bonds are usually regarded as a form of deferred equity financing. ${ }^{62}$ On this view, the "interest" payments can be equated with guaranteed payments to people with an "equity" position, during an interim period in which they are not quite, but almost, shareholders. ${ }^{63}$ In other words, why cannot the government take the financial analysts and the corporate financial officers at their words, treat all convertible bondholders like shareholders and, based on this anlysis, deny the corporation a deduction for the "interest" payments made to them? While it appears to be too late in the game for the Treasury to do this by administrative fiat, ${ }^{64}$ the possibility is one that seems worthy of some consideration in Congress.

\section{APPENDIX \\ The Relative Value of the Bond and the Conversion Privilege}

Imagine that $X$ Corporation has just announced its decision to issue a $\$ 1,000$ face value convertible subordinated debenture bearing a coupon rate of six percent, convertible at $\$ 25$ per share, with a maturity date ten years hence and redeemable at par on sixty days notice. It plans to sell the bond at par. Susan the Speculator sees this as her opportunity to buy a long term option on $X$ Corporation stock (although recognizing that

61 Under current law, convertibility is merely one element used in determining whether a security that purports to be debt is in substance equity. See INT. REv. CoDE of 1954, $\$ \S 279,385$; Symposium, Convertible Debentures and Strange Securities, 28 N.Y.U. Insr. ON FED. TAX. 331, 334-45, 337-38, 340 (1970). The advantage of deductibility is reduced by the fact that the original-issue discount that is hidden by the conversion feature cannot be deducted through amortization. See note 39 supra. There is, however, a corresponding advantage to the purchaser that should increase the price at which the bond can be sold.

${ }^{62} \mathrm{My}$ objections to the deferred equity theory of convertible bonds, see text accompanying notes 33-38 supra, were not directed against that theory as a description of what corporations do, but against the supposed wisdom of such a financing policy. As such, those earlier objections present no obstacle to the proposal advanced in this section.

${ }^{63}$ See note 32 supra (quotation from Pinches).

${ }^{64}$ See authorities cited in note 61 supra, particularly INT. Rev. CODE OF 1954, $\S 385$, which was adopted in 1969 and which provides that convertibility is one factor that can be taken into account in determining whether the interest on corporate "debt" should be deductible. 
the company's freedom to redeem limits the potential duration of the option and the potential profit from it). Susan has no interest in the safety and security associated with the bond element. She approaches her friend Ida the Investor, suggesting a joint purchase of the bond with a division of its elements between them. Ida has indicated an interest in such a deal and the two women have just begun to talk about the terms of their joint ownership. They have agreed that if $X$ Corporation were to issue a straight bond that is otherwise identical, it would sell for $\$ 900$. Their dialogue continues as follows.

$S$ : It seems to me that the first thing we have to agree on is that I will be allowed to exercise the conversion privilege whenever I want and pay you off in cash.

$I$ : Now hold on right there. What if the market interest rate has fallen, but not enough to induce the company to redeem? I would have a good deal, but by converting, you deprive me of that advantage. If you were required to take account of my loss, you might not convert.

$S$ : Agreed. I will compensate you for any such loss on conversion. But, by the same token, you should compensate me for any gain you realize if the market interest rate has risen.

I: That seems fair enough, but it shifts to you an element of the investment package that I would like to have and that you probably don't care about. If you decide to convert before maturity, gain or loss in the value of the bond element attributable to changes in the market rate of interest is eliminated. Thus, to the extent of the possibility of such an outcome, we have a hedge against changes in the market rate of interest. A risk-averse person like me would be willing to pay something for that hedge. But by virtue of the agreement we have just reached, I wind up losing the hedge and you wind up taking a gamble that you might not really want.

$S$ : True enough. What we want to do is shift the hedge element to you. But without the initial agreement, my decision will not necessarily be a sensible one for both of us, because I won't be required to take account of the effects on you.

I: Why don't we modify the agreement to provide that there will be no compensation, but that in making your decision you must act as if compensation were required? Because the decision to convert should be determined by objective factors, I believe that such an agreement will be workable and enforceable, though perhaps we should think some more about this. 
$S$ : O.K., but if we do adopt such an agreement, we will have created an element of value and assigned it to you. So you ought to compensate me by paying a greater share of the total cost of the investment than you would otherwise pay.

I: By golly, aren't you the clever one? It seems to me that what we have here is a synergistic relationship. It's like the apples and oranges paradigm that old Klein used to bore us with when we were law students. We've got a mixed bag and the separate elements are worth more to us than the mixed bag costs. But that leaves us with a problem in game theory, doesn't it? Suppose, for example, that the mixed bag of apples and oranges would cost $\$ 3$ and that you would pay $\$ 2$ for the apples and nothing for the oranges and I would pay $\$ 2$ for the oranges and nothing for the apples? What would you say if I offered to sell you the apples for $\$ 1.95$ ?

$S$ : Something crude, I suppose, but I see your point. There is no principle that tells us what each of us should pay, and the same is true for the added value that we create by splitting up the two elements of the convertible bond package.

I: Well, let's assume that we will be able to reach some agreement, if we can ever figure out the value of what it is that we are creating with all this synergy. Remember, by the way, that this value disappears if you convert. But I've got another issue. Again we're agreed that a straight bond of this company, with the same features, would sell for $\$ 900$. On the other hand, if you convert, the bond is worth $\$ 1,000$ to you for the purpose of buying the stock. Assuming that there is some prospect that you may convert before maturity, how much do I get?

$S$ : Hold on a second. I'm not sure that I agree that the bond is worth $\$ 1,000$ to me if I convert. The conversion price just tells me how many shares I can get on conversion-in this case, forty. That's all I'm interested in. By converting, neither you nor I give up $\$ 1,000$, though it's true that from the company's perspective the stock will have been sold for $\$ 25$ per share, ignoring the cost of the free ride and the interest paid until conversion. Suppose I pay $\$ 100$ for the option-that is, for the right to the forty shares upon surrender of the bond. That's a sunk cost once we buy the bond. In deciding to convert I would assume that my cost for the stock is whatever you are entitled to for your pure bond element (including, of course, any side payment I have to make under our earlier agreement relating to changes in the interest rate). I would ignore my sunk cost of $\$ 100$. 
I: O.K., we seem to have come to the nub of the issue: how much do you pay me for the bond element, assuming there has been no change in the market rate of interest?

$S$ : That's pretty obvious, isn't it? You invest $\$ 900$ so I pay you back $\$ 900$.

I: Come now, Sue. You know I'm not that dumb. When we came up with the $\$ 900$ figure we implicitly assumed that part of my return is the prospect of receiving $\$ 1,000$ on maturity, ten years from the date of issuance. You know that. So I ought to get an extra $\$ 10$ for each year towards maturity.

$S:$ I always said that a body has to get up awfully early in the morning to catch old Ida in bed. Can we cut out the games now and agree that you will receive $\$ 900$ plus an amount such that, if held to the maturity date of the bond, you would have $\$ 100$ ?

I: At what rate of interest?

$S$ : Son of a gun, here we go again. Let's say the then current market interest rate. And to avoid repeating that synergy and game theory discussion, just be my guest.

I: I think we've got a deal. By the way, what about commissions? How do we divide those?

$S$ : Please, I'm developing a headache. Let's talk about that some other time.

I: O.K., but overnight you might also begin to think about what happens if the company calls the bond. Obviously we will convert if that produces a value greater than $\$ 1,000$; otherwise we take the $\$ 1,000$. But assuming that there has been a change in the market rate of interest, how do we split the proceeds? And one more thing ....

$S$ : Enough! Enough!

Exeunt. 